\title{
Investigation of phagotrophy in natural assemblages of the benthic dinoflagellates Ostreopsis, Prorocentrum and Coolia
}

\author{
Eliliane Vasconcelos Corrêa Almada ${ }^{*}$, Wanderson Fernandes de Carvalho ${ }^{2}$, Silvia Mattos \\ Nascimento $^{2}$
}

\author{
${ }^{1}$ Universidade Estadual do Norte Fluminense Darcy Ribeiro \\ (Av. Alberto Lamego, 2000 - Campos dos Goytacazes - 28035-200 - Rio de Janeiro - Brazil) \\ ${ }^{2}$ Universidade Federal do Estado do Rio de Janeiro, UNIRIO \\ (Av. Pasteur, 436 - Urca - 22290-240 - Rio de Janeiro - Brazil) \\ *Corresponding author: elilianealmada@gmail.com
}

\section{Abstract}

Mixotrophy has been shown to be a common trait among dinoflagellates and its importance in the nutritional ecology of harmful algae has been hypothesized. Benthic harmful species have not been extensively investigated as their planktonic counterparts and there are major gaps in the knowledge of their nutritional strategies. In this study the occurrence of phagotrophy was investigated in natural assemblages of benthic dinoflagellates using epi-fluorescence microscopy with DAPI and LysoSensor staining. The study was conducted at five sites along the coast of Rio de Janeiro that were visited in January, August and December 2010. In total, 1659 dinoflagellate cells were observed. From these, only $0.4 \%$ of 1195 Ostreopsis cf. ovata and $2.2 \%$ of 134 Coolia spp. cells presented evidence of phagotrophy with vacuoles stained by LysoSensor or a DAPI (4',6-diamidino-2-phenylindole) stained inclusion. Stained vacuoles were not registered in the 330 Prorocentrum spp. cells observed. Few $O$. cf. ovata cells contained round red inclusions ("red spots") that were not stained either by DAPI or LysoSensor, suggesting that these structures are not ingested prey. The results showed that phagotrophy was not a frequent nutritional strategy in benthic dinoflagellates during the study period.

Descriptors: Dinoflagellates, LysoSensor, Mixotrophy, Phagotrophy.

\section{RESUMO}

A mixotrofia tem se mostrado uma característica comum entre dinoflagelados e a sua importância na ecologia nutricional de algas nocivas vem sendo investigada. Espécies bentônicas nocivas não foram tão estudadas quanto as planctônicas, e existem grandes lacunas no conhecimento de suas estratégias nutricionais. A ocorrência de fagotrofia em comunidades naturais de dinoflagelados bentônicos foi investigada usando microscopia de epi-fluorescência e marcação por DAPI e LysoSensor. O estudo foi realizado em cinco locais ao longo da costa do Rio de Janeiro nos meses de janeiro, agosto e dezembro de 2010. No total, foram observadas 1659 células de dinoflagelados. Destas, apenas 0,4\% das 1195 células de Ostreopsis cf. ovata e 2,2\% das 134 células de Coolia spp. observadas apresentaram evidências de fagotrofia com vacúolos marcados por LysoSensor ou inclusão celular marcada por DAPI (4', 6-diamidino-2-phenylindole). Não foram observados vacúolos marcados nas 330 células de Prorocentrum spp. observadas. Células de $O$. cf. ovata apresentaram inclusões esféricas avermelhadas ("red spots") que não foram coradas por DAPI e LysoSensor, sugerindo que estas estruturas não correspondem a presas ou a vacúolos digestivos. Os resultados mostraram que a fagotrofia não foi uma estratégia nutricional frequente nas espécies de dinoflagelados bentônicos observadas durante o período de estudo.

Descritores: Dinoflagelados, LysoSensor, Mixotrofia, Fagotrofia. 


\section{INTRODUCTION}

Mixotrophs are organisms that are capable of combining phototrophic and heterotrophic nutrition to obtain energy (JONES, 1994). Algal mixotrophs vary from species with poor efficiency as phototrophs but high efficiency as phagotrophs to obligate phototrophs with minimal heterotrophy (STOECKER, 1998). Phagotrophy, consumption of particulate food or prey, refers to ingestion of discrete particles wherein digestion occurs in specialized phagocytic (food) vacuoles (GAINES; ELBRÄCHTER, 1987). Mixotrophy has been shown to be a common trait among dinoflagellates and was observed in species of several orders (STOECKER, 1999). Dinoflagellates represent 75 to $80 \%$ of all known harmful species (CEMBELLA, 2003) and form extensive blooms. It has been hypothesized that the association of mixotrophy with the allelopathic effects of toxins against predators and competitors may represent an ecological advantage in harmful algae bloom initiation and persistence (BURKHOLDER et al., 2008).

Studies regarding the nutritional strategies of benthic harmful dinoflagellates such as species of the genera Ostreopsis, Gambierdiscus, Prorocentrum and Coolia are scarce. Benthic harmful species have not been extensively investigated as their planktonic counterparts and there are major gaps in the knowledge of their physiology, nutritional requirements and life cycles (GEOHAB, 2012). Harmful events associated with outbreaks of benthic dinoflagellates have been reported more frequently over the last decade, including in areas where benthic harmful genera were hardly known (GEOHAB, 2012).

Several species of Ostreopsis produce potent neurotoxins of the palytoxin group (CIMINIELLO et al., 2008; 2010) that have been associated with human seafood poisoning through the consumption of fish (TANIYAMA et al., 2003; AMZIL et al., 2012). Recurrent massive blooms of Ostreopsis cf. ovata have been reported in the Mediterranean Sea where they have been associated with impacts on marine invertebrate (FAIMALI et al., 2012) as well as humans health through inhalation (CIMINIELLO et al. 2006; 2010) and severe skin irritations (DEEDS; SCHWARTZ, 2010). In Brazil, O. cf. ovata blooms are frequent in Rio de Janeiro (NASCIMENTO et al., 2012a) and have also been reported at Saint Paul's
Rocks (NASCIMENTO et al., 2012b). Among the benthic species of Prorocentrum, at least nine produce harmful metabolites or toxins including okadaic acid (OA) and its analogues, dinophysistoxins (DTXs) (HOPPENRATH et al., 2013) that are responsible for shellfish poisoning (DSP). DSP is a human illness caused by the consumption of shellfish contaminated with OA and DTXs. In the genus Coolia, C. monotis from Australia, was reported to produce cooliatoxin (HOLMES et al., 1995) and WAKEMAN et al. (2015) reported that Coolia malayensis produces unique metabolites related to cooliatoxin and yessotoxin analogs.

Mixotrophy has been previously reported in benthic dinoflagellates such as Ostreopsis cf. ovata, Ostreopsis lenticulares, Ostreopsis siamensis, Ostreopsis labens, Prorocentrum belizeanum, Prorocentrum hoffmannianum, Prorocentrum arenarium and Gambierdiscus toxicus through the identification of prey inside cells (FAUST; MORTON, 1995; FAUST et al., 1996; FAUST, 1998). Using light microscopy, organisms such as cyanobacteria, centric diatoms, ciliates and small microalgae have been identified as prey for benthic dinoflagellates in Belize (FAUST, 1998; FAUST; MORTON, 1995; FAUST et al., 1996), although the feeding behavior has not been observed. These authors suggested that mixotrophy may be common among Ostreopsis species.

Mixotrophy is often difficult to detect in dinoflagellates for several reasons. The use of markers for digestive vacuoles can be an alternative to facilitate the investigation of phagotrophy. LysoSensor probes are selectively concentrated and become more fluorescent in acidic organelles such as food vacuoles. This probe has been successfully used to study phagotrophy in the dinoflagellates Oxyrrhis marina and Dinophysis norvegica and in the haptophyte Prymnesium parvum and food vacuoles were detected by both fluorescence microscopy and flow cytometry (BOWERS et al., 2010; CARVALHO; GRANÉLI, 2006; CARVALHO; GRANÉLI, 2010).

In this paper we investigated the occurrence of phagotrophy in natural assemblages of benthic dinoflagellates from Rio de Janeiro coastal areas using the nuclear (DNA) dye DAPI to stain the nucleus of prey inside dinoflagellates, and the food vacuole marker LysoSensor. 


\section{MATERIAL AND METHODS}

Two fluorescence methods (staining the nucleus of potentially ingested prey and staining food vacuoles) were used to investigate phagotrophy in cells of benthic dinoflagellates associated to macroalgae at the Rio de Janeiro coastline. Sampling sites comprised rocky shores on shallow embayment along Armação dos Búzios $\left(22^{\circ} 45^{\prime} 18^{\prime \prime}\right.$ S, 41 ${ }^{\circ} 54^{\prime} 07^{\prime \prime}$ W) and Arraial do Cabo (22 $57^{\circ} 58^{\prime \prime}$ S, 42 01 '40”W) (Fig. 1, Table 1).

\section{DAPI STAINING OF INGESTED PREY}

In January 2010 macroalgal samples were collected from a depth of 1-3 $\mathrm{m}$ by snorkel diving from sites 1 and 2 (Table 1). Specimens of macroalgae were placed in sealable plastic bags with $50 \mathrm{~mL}$ of filtered seawater and were vigorously shaken for 2 minutes to detach the associated epiphytic cells. The epiphytic suspension was filtered through a $125 \mu \mathrm{m}$ mesh to remove larger particles and debris. Pigments from microalgae cells present in the epiphytic suspension were removed following the procedure described by SALOMON et al. (2003) with slight modifications (fixation with phosphate buffered saline solution containing paraformaldehyde) previous to dinoflagellate cells observation under fluorescence microscopy with UV (365 nm) filter (Olympus BX51, USA). This procedure was applied to avoid the interference of chlorophyll auto fluorescence on the visualization of DAPI staining. The fluorochrome DAPI was used to stain the nucleus of ingested prey inside benthic dinoflagellates, although it is possible that the nucleus of parasites would be stained as well. Two $\mu \mathrm{L}$ of DAPI $(50 \mu \mathrm{g}$ $\mathrm{mL}^{-1}$ ) were added to $100 \mu \mathrm{l}$ of the solution containing benthic dinoflagellates.

The solution was kept in the dark until observation. Benthic dinoflagellates were observed using an Olympus microscope (Olympus BX51, USA) with phase contrast, differential interference contrast under light and epifluorescence microscopy with UV $(365 \mathrm{~nm})$ filter (Olympus BX51, USA). The presence of blue stained inclusions or other structures like vesicles or red inclusions was registered when present.

\section{LYSOSENSOR STAINING OF FOOD VACUOLES}

Macroalgal samples were collected in sites 2, 3 and 4 in August 2010 while sites 3, 4 and 5 were visited in
December 2010 (Table 1, Fig. 1). Benthic dinoflagellates were detached from their substrates as described above. Cells of Ostreopsis, Prorocentrum and Coolia present in the epiphytic suspension were concentrated in a $20 \mu \mathrm{m}$ mesh and were then resuspended in $30 \mathrm{~mL}$ of filtered (glass-fiber filter, Millipore AP-40, Millipore Brazil) seawater. Two $\mu \mathrm{L}$ of the LysoSensor ${ }^{\mathrm{TM}}$ Yellow/Blue DND-160 (PDMPO) solution (1mM) (Molecular Probes, Oregon, USA) were added to $1 \mathrm{~mL}$ of the concentrated epiphytic suspension (probe final concentration: $1 \mu \mathrm{M}$ ) that was left in the dark for $5 \mathrm{~min}$ before observation under light and epi-fluorescence microscopy with UV (365 nm) filter (Olympus BX51, USA). According to the manufacturers, LysoSensor Probes are weak bases that are selectively concentrated in acidic organelles after protonation, turning bright fluorescent in acidic environments. The LysoSensor ${ }^{\mathrm{TM}}$ Yellow/Blue probe is unique in that it exhibits both dual-excitation and dualemission spectral peaks that are $\mathrm{pH}$-dependent and have predominantly yellow fluorescence in acidic organelles when excited by blue light $(488 \mathrm{~nm})$, and blue fluorescence in less acidic organelles when excited by UV light (360 $\mathrm{nm})$.

DAPI and LysoSensor were not applied in combination because epi-fluorescence microscopy was used to observe the cells and LysoSesor should be used in live cells during short incubations (one to two minutes) and as soon as samples are collected. This prevents the use of procedures necessary to remove pigments from the cells to avoid their auto fluorescence from masking DAPI staining.

\section{RESULTS}

In total, 1659 dinoflagellate cells were counted during this study; most of them $O$. cf. ovata ( 1195 cells). In January 2010 , the DAPI fluorochrome worked successfully as the nucleus of $O$. cf. ovata cells was stained (Fig. 2). Among the 255 O. cf. ovata cells examined in January 2010, only one presented a DAPI-stained inclusion close to the ventral area of the cell (Fig. 2). Colorless and irregularly shape vesicles were observed in $42 \mathrm{O}$. cf. ovata cells, but were not stained by DAPI (Fig. 3).

In August and December 2010 the effectiveness of the LysoSensor probe was confirmed by staining the digestive tract of ciliates collected locally (data not shown). Among the 227 O. cf. ovata cells examined in August, only one 


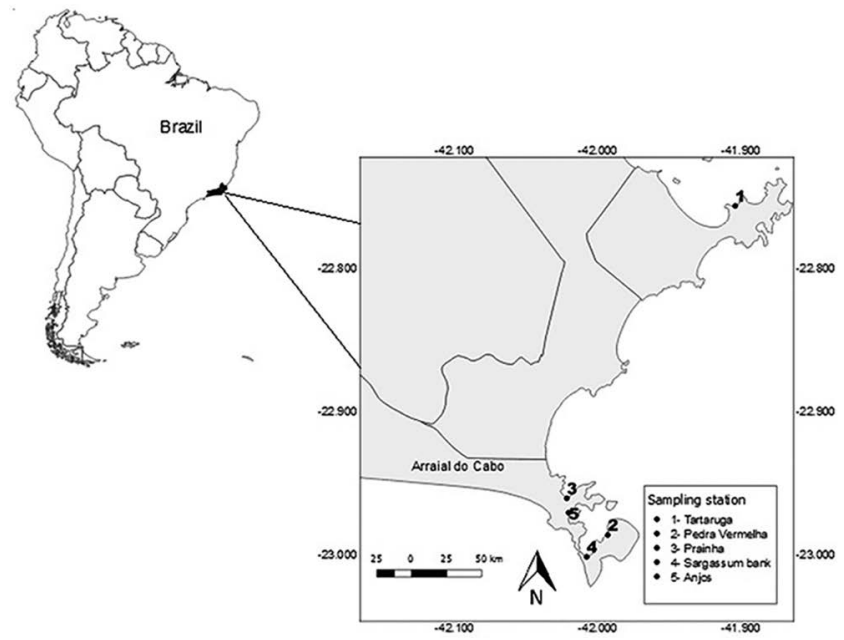

Figure 1. Map of South America showing the location of Brazil and Rio de Janeiro state. The "inlet" shows a detailed map of the sampling stations in Armação dos Búzios and Arraial do Cabo cities.

Table 1. Sampling stations, list of macroalgae species collected in January (Summer), August (Winter) and December (Summer) 2010 along the Rio de Janeiro coastline and staining method used to identify phagotrophy. Numbers in brackets represent the number of specimens collected of each species.

\begin{tabular}{|c|c|c|c|c|}
\hline $\begin{array}{l}\text { Month/ } \\
2010\end{array}$ & Sampling station & & Macroalgae species & Staining method \\
\hline \multirow[b]{2}{*}{ January } & Tartaruga & site 1 & Sargassum vulgare (8) & \multirow[b]{2}{*}{ DAPI } \\
\hline & $\begin{array}{l}\text { Pedra Vermelha, } \\
\text { Cabo Frio Island }\end{array}$ & site 2 & Sargassum vulgare (4), Spyridia sp. (1), Amphiroa spp. (4) & \\
\hline \multirow{3}{*}{ August } & Prainha & site 3 & Jania capillacea + Amphiroa fragilissima (1), Amphiroa fragilissima (3) & \multirow{3}{*}{ LysoSensor } \\
\hline & Sargassum bank & site 4 & $\begin{array}{l}\text { Amphiroa fragilissima (2), Jania capillacea }+ \text { Amphiroa fragilissima } \\
\text { (1), Spyridia } \mathrm{sp} . \text { (1) }\end{array}$ & \\
\hline & $\begin{array}{l}\text { Pedra Vermelha, } \\
\text { Cabo Frio Island }\end{array}$ & site 2 & Amphiroa spp. (1), Amphiroa spp. + Hypnea spinella (1) & \\
\hline \multirow{3}{*}{ December } & Prainha & site 3 & Amphiroa spp. (2), Spyridia sp. (1) & \multirow{3}{*}{ LysoSensor } \\
\hline & Sargassum bank & site 4 & Sargassum vulgare (1), Padina gymnospora (1), Amphiroa spp. (1) & \\
\hline & Anjos & site 5 & Sargassum vulgare (1), Spyridia sp. (1) & \\
\hline
\end{tabular}

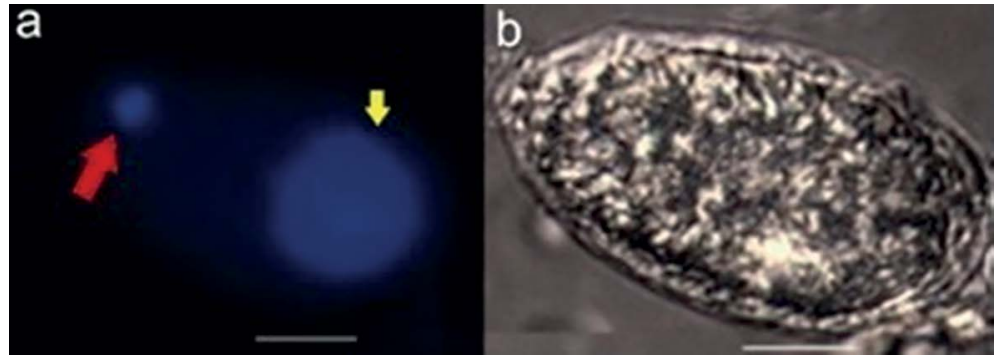

Figure 2. a- Epi-fluorescence microscopy with UV emission. b- Light Microscopy. Micrographs of a cell of $O$. cf. ovata with a DAPI stained inclusion (larger red arrow), january 2010. The posterior nucleus is stained by DAPI (lower yellow arrow). Scale bar $=10 \mu \mathrm{m}$. 

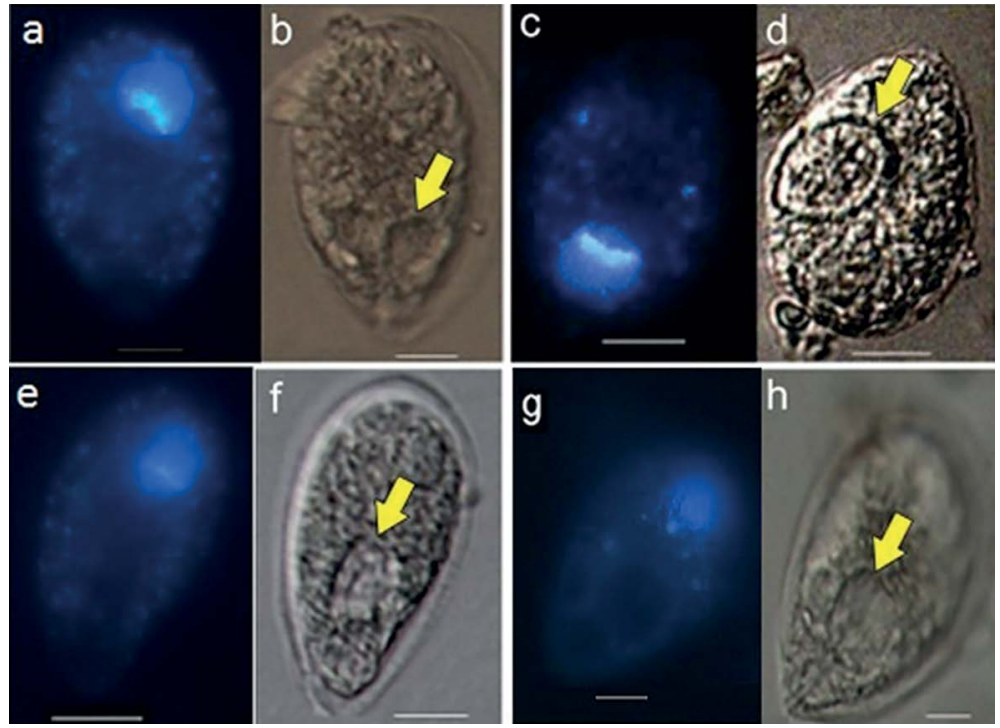

Figure 3. a,c, e, g - Epi-fluorescence microscopy with UV emission. b, d, f, h - Light microscopy. Micrographs of $O$. cf. ovata cells with round vesicles (yellow arrows), January 2010. Note posterior nucleus stained by DAPI. Scale bar $=10 \mu \mathrm{m}$.

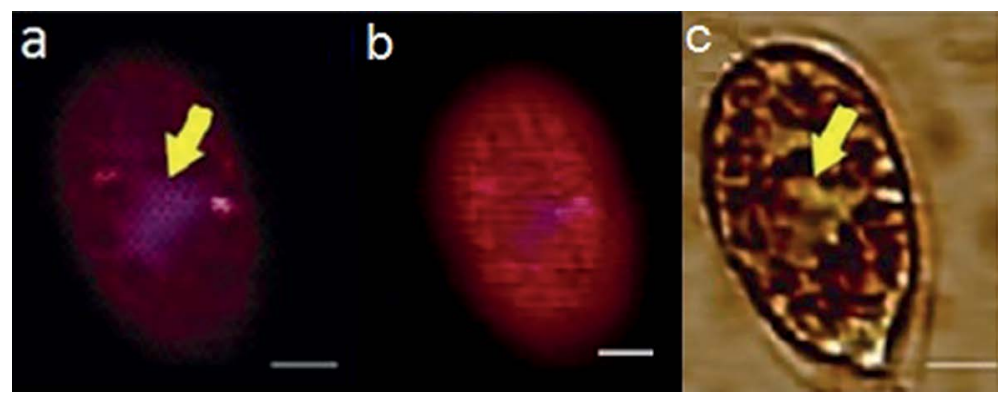

Figure 4. a, b - Epi-fluorescence microscopy with UV emission. c - Light microscopy. Micrographs of $O$. cf. ovata cell with vesicle stained by LysoSensor, August 2010. aLysoSensor (blue) stained vesicle (yellow arrow). b- Fading fluorescence approximately $3 \mathrm{~min}$ later c. vesicle under light microscopy. Scale bar $=10 \mu \mathrm{m}$.

cell presented a blue-stained vesicle resembling a food vacuole (Fig. 4).

In December 2010, 713 O. cf. ovata cells and 134 Coolia spp. cells were observed and only three cells of each species showed stained structures similar to food vacuoles (Fig. 5). Food items could not be identified inside the stained digestive vacuoles. Stained structures were not registered in the 330 cells of Prorocentrum spp. (mainly Prorocentrum lima, but also Prorocentrum mexicanum).

Ostreopsis cf. ovata cells containing a round red inclusion under light microscopy and natural orange fluorescence under epi-fluorescence (Fig. 6) were observed in January and December 2010. The structure resembles what some authors call a "red spot" or "red body". In total, eight cells containing red bodies were recorded, three in January and five in December (two at site 3 and three at site 5). None of these red spots were stained either by DAPI or LysoSensor (Fig. 6). The red spots were not seen in cells of Prorocentrum spp. and Coolia spp.

\section{DISCUSSION}

In the current study, only a small percentage $(0.4 \%$ of O. cf. ovata and $2.2 \%$ of Coolia) of the dinoflagellate cells presented evidence of phagotrophy (vesicles stained by LysoSensor or a DAPI stained inclusion) and no prey was discernible inside the cells of Ostreopsis, Prorocentrum and Coolia. FAUST (1998) reported that between 7 and $55 \%$ of the Ostreopsis species from Belize contained a variety of prey. To identify mixotrophic nutrition based on the observation of particles inside a protist cell by light microscopy is challenging (CARVALHO; GRANÉLI, 


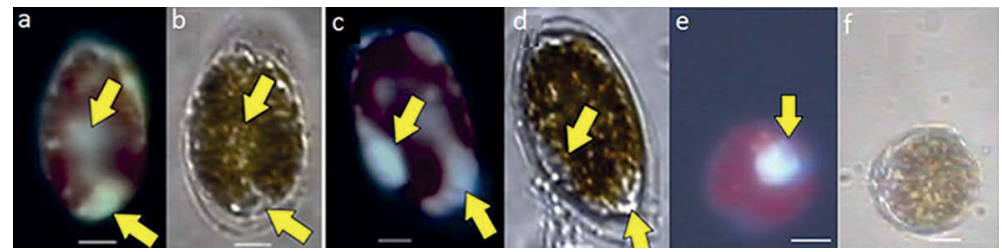

Figure 5. a, c, e - Epi-fluorescence microscopy with UV emission. b, d \& f- Light microscopy. Micrographs of $O$. cf. ovata and Coolia sp. cells with vesicles stained by LysoSensor (yellow arrows), December 2010. a, b, c, d- O. cf. ovata cells; e, f Coolia sp. Scale bar $=10 \mu \mathrm{m}$.
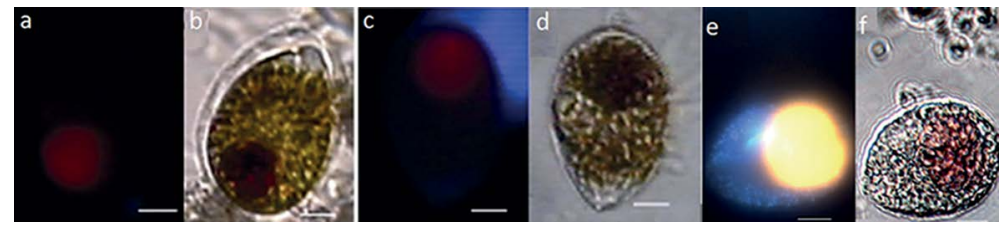

Figure 6. a, c, e - Epi-fluorescence microscopy with UV emission. b, d, f - Light microscopy. Micrographs of $O$. cf. ovata cells with round reddish inclusions with orange fluorescence. a, b- DAPI staining assay. c, d, e, f- LysoSensor assay, note that the red spots are not stained by LysoSensor. Scale bar $=10 \mu \mathrm{m}$.

2006). Chloroplasts may mask food vacuoles and it can be problematic to distinguish food vacuoles from other types of inclusions such as gametes or parasites (GRANÉLI; CARLSSON, 1998; LEGRAND et al., 1998; CARVALHO and GRANÉLI, 2006). In an early stage of the infection, parasites can be easily misidentified as prey. Moreover, the cytoplasm of dinoflagellates is highly vesiculate and many species contain "accumulation bodies" or "polyvesicular bodies" whose function is probably the breakdown of superfluous organelles and membranes (VAN DEN HOEK et al., 1995). The cytoplasm of the most conspicuous benthic dinoflagellate, $O$. cf. ovata was shown to contain accumulation bodies, cytosolic lipid droplets, rounded translucent bodies, membranous material often surrounded by smooth endoplasmic reticulum and a large number of fibrous material containing vesicles delimited by two membranes, and likely to represent the pusule (HONSELL et al., 2013). This complex cytoplasmic structure adds some difficulty to the observation of food vacuoles or ingested prey through the observation solely by light microscopy.

Therefore, it is likely that early investigations of mixotrophy in benthic dinoflagellates (FAUST; MORTON, 1995) based on light microscopy observations may have overestimated the occurrence of phagotrophy in these species. In the current study, vesicles not stained by LysoSensor were observed.

FAUST and MORTON (1995) reported the presence of large ingested particles or food vacuolated cells containing engulfed prey with an intense red color in $O$. labens. Those authors speculated that the ventral plate with associated opening is a peduncle-like structure that is the feeding apparatus of $O$. labens, although prey ingestion was not described or illustrated by them. More recently, ESCALERA et al. (2014) interpreted a strand of tightly adpressed microtubules within the sulcal area of the closely related species $O$. cf. ovata as the microtubular strand of the peduncle (MSP). However, these authors stated that a peduncle was never observed in culture or field samples of $O$. cf. ovata, nor was it detected in any TEM sections and that a peduncle-homologous microtubular strand was reported in Palatinus apiculatus (CRAVEIRO et al., 2009), a species that lacks a peduncle (ESCALERA et al., 2014). ESCALERA et al. (2014) provided evidence that the ventral opening of $O$. cf. ovata plays a role in mucus excretion.

The red spots that were observed in $O$. cf. ovata cells in the current study were not stained by LysoSensor, suggesting that they are not digestive vacuoles.

FAUST and MORTON (1995) and FAUST (1998) described these reddish round inclusions and considered them as prey in $O$. lenticulares and $O$. labens observed under light microscopy. The presence of a red-pigmented structure is widely described in the literature on dinoflagellate cysts (GRAHAM; WILCOX, 2000). It has been called as red-spots, red-brown spots or dark-brown material by a number of authors. The cells with red spots observed in the current study are similar to the $O$. cf. ovata cysts observed in cultures and field samples by ALIGIZAKI and NIKOLAIDIS (2006), BRAVO et al. (2012) and 
ACCORONI et al. (2014). Red bodies in Ostreopsis cysts enclosed in hyaline membranes were observed mainly at the end of the bloom by ALIGIZAKI and NIKOLAIDIS (2006). MEKSUMPUN and MONTANI (1995) reported that red-brown inclusions in the marine dinoflagellate Scrippsiella trochoidea are composed of fucoxanthin, 19' hexanoyl - fucoxanthin, diadinoxanthin and diatoxanthin. The authors suggested that these pigments are useful for growth of vegetative cells after germination from cysts.

Differences in environmental conditions such as irradiance; nutrient concentrations (limited/sufficient) and prey availability have been reported to influence the occurrence of phagotrophy in dinoflagellate species (LEGRAND et al., 1998; STOECKER et al., 2006). The planktonic dinoflagellate Prorocentrum minimum was induced to prey in limiting nitrogen and phosphorus experimental conditions and feeding was never observed under nutrient replete conditions (JOHNSON, 2015). The study area is among the most productive regions in the Brazilian littoral due to the occurrence of coastal upwelling, particularly during austral summer that sustains high primary productivity and marine biodiversity (VALENTIN, 1984; GONZALEZ-RODRIGUEZ et al., 1992). Therefore, it is likely that benthic dinoflagellates from the study area were nutrient sufficient, a condition that would not stimulate the occurrence of phagotrophy. Data presented herein did not support phagotrophy as a common nutritional strategy among benthic dinoflagellates. Further studies including laboratory experiments under different environmental conditions are necessary to assess the capability of phagotrophy in benthic dinoflagellates.

\section{ACKNOWLEDGEMENTS}

The authors are indebted to the Instituto de Estudos do Mar Almirante Paulo Moreira (IEAPM) and to Dra. Eliane González-Rodríguez for all the assistance provided during field trips. This research was funded by Fundação Carlos Chagas Filho de Amparo à Pesquisa do Estado do Rio de Janeiro (FAPERJ- Brazil to SMN, grant number E26/111.925/2012) and Conselho Nacional de Desenvolvimento Científico e Tecnológico (CNPq Brazil to SMN, grant number 481150/07-2).

\section{REFERENCES}

ALIGIZAKI, K.; NIKOLAIDIS, G. The presence of the potentially toxic genera Ostreopsis and Coolia (Dinophyceae) in the North Aegean Sea, Greece. Harmful Algae, v. 5, n. 3, p. 717-730, 2006.
ACCORONI, E.; ROMAGNOLI, T.; PICHIERRI, S.; TOTTI, C. New insights on the life cycle stages of the toxic benthic dinoflagellate Ostreopsis cf. ovata. Harmful Algae, v. 34, p. 7-16, 2014.

AMZIL, Z.; SIBAT, M.; CHOMERAT, N.; GROSSEL, H.; MARCO-MIRALLES, F.; LEMEE, R.; NEZAN, E.; SECHET, V. Ovatoxin-a and palytoxin accumulation in seafood in relation to Ostreopsis cf. ovata blooms on the French Mediterranean coast. Mar. Drugs, v. 10, n. 2, p. 477-496, 2012.

BOWERS, H. A.; BRUTEMARK, A.; CARVALHO, W. F.; GRANÉLI, E. Combining Flow Cytometry and Real-Time PCR Methodology to Demonstrate Consumption by Prymnesium parvum. J. Am. Water Works Assoc., v. 46, n. 1, p. 133-143, 2010.

BRAVO, I.; VILA, M.; CASABIANCA, S.; RODRIGUEZ, F.; RIAL, P.; RIOBÓ, P.; PENNA, A. Life cycle stages of the benthic palytoxin-producing dinoflagellate Ostreopsis cf. ovata (Dinophyceae). Harmful Algae, v. 18, p. 24-34, 2012.

BURKHOLDER, J. M.; GLIBERT, P. M.; SKELTON, H. M. Mixotrophy, a major mode of nutrition for harmful algal species in eutrophic waters. Harmful Algae, v. 8, n. 1, p. 77-93, 2008.

CARVALHO, W. F.; GRANÉLI, E. Acidotropic probes and flow cytometry: a powerful combination for detecting phagotrophy in mixotrophic and heterotrophic protists. Aquat. Microb. Ecol., v. 44, n. 1, p. 85-96, 2006.

CARVALHO, W. F.; GRANÉLI, E. Contribution of phagotrophy versus autotrophy to Prymnesium parvum growth under nitrogen and phosphorus sufficiency and deficiency. Harmful Algae, v. 9, n. 1, p. 105-115, 2010.

CEMBELLA, A. D. Chemical ecology of eukaryotic microalgae in marine ecosystems. Phycologia, v. 42, n. 4, p. 420-447, 2003.

CIMINIELLO, P.; DELL'AVERSANO, C.; FATTORUSSO, E.; FORINO, M.; TARTAGLIONE, S.; GRILLO, C.; MELCHIORRE, N. Putative palytoxin and its new analogue, ovatoxin-a, in Ostreopsis ovata collected along the Ligurian coasts during the 2006 toxic outbreak. J. Am. Soc. Mass Spectrom., v. 19, n. 1, p. 111-120, 2008.

CIMINELLO, P.; DELL'AVERSANO, C.; FATTORUSSO, E.; FORINO, M.; MAGNO, G. S.; TARTAGLIONE, L.; GRILLO, C.; MELCHIORRE, N. The Genoa 2005 outbreak. Determination of putative palytoxin in Mediterranean Ostreopsis ovata by a new liquid chromatography tandem mass spectrometry method. Anal. Chem., v. 78, n. 17, p. 6153-6159, 2006.

CIMINELLO, P.; DELL'AVERSANO, C.; DELLO IACOVO E.; FATTORUSSO, E.; FORINO, M.; GRAUSO, L.; TARTAGLIONE, L.; GUERRINI, F.; PISTOCCHI, R. Complex palytoxin-like profile of Ostreopsis ovata. Identification of four new ovatoxins by high-resolution liquid chromatography/mass spectrometry. Rapid Commun. Mass Spectrom., v. 24, n. 18, p. 2735-2744, 2010.

CRAVEIRO, S. C.; CALADO, A. J.; DAUGBJERG, N.; MOESTRUP, O. Ultrastructure and LSU rDNA-based revision of Peridinium group Palatinum (Dinophyceae) with the description of Palatinus gen. nov. J. Phycol., v. 45, n. 5, p. 11751194, 2009.

DEEDS, J. R.; SCHWARTZ, M. D. Human risk associated with palytoxin exposure. Toxicon, v. 56, n. 2, p. 150-162, 2010.

ESCALERA, L.; BENVENUTO, G.; SCALCO, E.; ZINGONE, A.; MONTRESOR, M. Ultrastructural Features of the Benthic Dinoflagellate Ostreopsis cf. ovata (Dinophyceae). Protist, v. 165, n. 3, p. 260-274, 2014. 
FAIMALI, M.; GIUSSANI, V.; PIAZZA, V.; GARAVENTA, F.; CORRÀ, C.; ASNAGHI, V.; PRIVITERA, D.; GALLUS, L.; CATTANEO-VIETTI, R.; MANGIALAJO, L.; CHIANTORE, M. Toxic effects of harmful benthic dinoflagellate Ostreopsis ovata on invertebrate and vertebrate marine organisms. Mar. Environ. Res., v. 76, p. 97-107, 2012.

FAUST, M. A. Mixotrophy in tropical benthic dinoflagellates. In: REGUERA, B.; BLANCO, J.; FERNÁNDEZ, M. L.; WYATT, T. (Ed.). VIII International Conference on Harmful Algae. Vigo: International Oceanographic Comission of UNESCO, 1998. p. 390-393.

FAUST, M. A.; MORTON, S. L. Morphology and ecology of the marine dinoflagellate Ostreopsis labens sp. nov. (Dinophyceae). J. Phycol., v. 31, n. 3, p. 456-463, 1995.

FAUST, M. A.; MORTON, S. L.; QUOD, J. P. Further SEM study of marine Dinoflagellates: the genus Ostreopsis (Dinophyceae). J. Phycol., v. 32, n. 6, p.1053-1065, 1996.

GAINES, G.; ELBRÄCHTER, M. Heterotrophic nutrition. In: TAYLOR, F. J. R. (Ed.). The Biology of Dinoflagellates. Palo Alto: Blackwell Scientific Publications, 1987. p. 224-268.

GEOHAB 2012. Global Ecology and Oceanography of Harmful Algal Blooms, GEOHAB Core Research Project: HABs in Benthic Systems. E. Berdalet, P. Tester, A. Zingone (Eds.) IOC of UNESCO and SCOR, Paris and Newark, 64 pp.

GONZALEZ-RODRIGUEZ, E., VALENTIN, J. L.; ANDRÉ, D. L.; JACOB, S. A. Upwelling and downwelling at Cabo Frio (Brazil): comparison of biomass and primary production responses. J. Plankton Res., v. 14, n. 2, p. 289-306, 1992.

GRAHAM, L. E.; WILCOX, L. W. Dinoflagellates. In: GRAHAM, J. E.; WILCOX, L. W.; GRAHAM, L. E. Algae. Upper Saddle River: Prentice Hall, 2000.

GRANÉLI, E.; CARLSSON, P. The ecological significance of phagotrophy in photosynthetic flagellates. In: ANDERSON, D. M.; CEMBELLA, A. D.; HALLEGRAEFF, G. M. (Eds.). Physiological ecology of harmful algal blooms, NATO ASI Series G41. Berlin: Springer-Verlag, 1998, p. 539-557.

HOLMES, M. J.; LEWIS, R. J.; JONES, A.; HOY, A. W. Cooliatoxin, the first toxin from Coolia monotis (Dinophyceae). Nat. Toxins, v. 3, n. 5, p. 355-362, 1995.

HONSELL, G.; BONIFACIO, A.; DE BORTOLI, M.; PENNA, A.; BATTOCCHI, C.; CIMINIELLO, P.; DELL'AVERSANO, C.; FATTORUSSO, E.; SOSA, S.; YASUMOTO, T.; TUBARO, A. New Insights on Cytological and Metabolic Features of $O s$ treopsis cf. ovata Fukuyo (Dinophyceae): A Multidisciplinary Approach. PLoS ONE, v. 8, n. 2, p. e57291, 2013.
HOPPENRATH, M.; CHOMÉRAT, N.; HORIGUCHI, T.; SCHWEIKERT, M.; NAGAHAMA, Y.; MURRAY, S. Taxonomy and phylogeny of the benthic Prorocentrum species (Dinophyceae) - A proposal and review. Harmful Algae, v. 27, p. 1-28, 2013.

JOHNSON, M. D. Inducible mixotrophy in the dinoflagellate Prorocentrum minimum. J. Eukaryot Microbiol., v. 62, n. 4, p. 431-443, 2015.

JONES, R. I. Mixotrophy in planktonic protists as a spectrum of nutritional strategies. Mar. Microb Food Webs, v. 8, n. 1, p. 87-96, 1994.

LEGRAND, C.; GRANÉLI, E.; CARLSSON, P. Induced phagotrophy in the photosynthetic dinoflagellate Heterocapsa triquetra. Aquat. Microb. Ecol., v. 15, p. 65-75, 1998.

MEKSUMPUN, S.; MONTANI, S. Chemical components of red-brown material in cyst of Scrippsiella trochoidea (Dinophyceae). Kasetsart Univ. Fish Res. Bull., v. 21, p. 1-16, 1995.

NASCIMENTO, S. M.; CORRÊA, E. V.; MENEZES, M; VARELA, D.; PAREDES, J.; MORRIS, S. Growth and toxin profile of Ostreopsis cf. ovata (Dinophyta) from Rio de Janeiro, Brazil. Harmful Algae, v. 13, p. 1-9, 2012a.

NASCIMENTO, S. M.; FRANÇA, J. V.; GONÇALVES, J. E. A.; FERREIRA, C. E. L. Ostreopsis cf. ovata (Dinophyta) bloom in an equatorial island of the Atlantic Ocean. Mar. Pollut. Bull., v. 64 , n. 5 , p. 1074-1078, 2012 b.

SALOMON, P. S.; JANSON, S.; GRANÉLI, E. Parasitism of Dinophysis norvegica by Amoebophrya sp. in the Baltic Sea. Aquat. Microb. Ecol., v. 33, n. 2, p. 163-172, 2003.

STOECKER, D. K. Conceptual models of mixotrophy in planktonic protists and same ecological and evolutionary implications. Eur. J. Protistol., v. 34, n. 3, p. 281-290, 1998.

STOECKER, D. K. Mixotrophy among dinoflagellates. J. Eukaryot. Microbiol., v. 46, n. 4, p. 397-401, 1999.

STOECKER, D. K.; TILLMANN, U.; GRANÉLI, E. Phagotrophy in harmful algae. In: GRANÉLI, E.; TURNER, J. (Eds.). Ecology of Harmful Algae. Berlin: Springer-Verlag, 2006. p. 177-187.

TANIYAMA, S.; ARAKAWA, O.; TERADA, M.; NISHIO, S.; TAKATANI, T.; MAHMUDA, Y.; NOGUCHI, T. Ostreopsis sp., a possible origin of palytoxin (PTX) in parrotfish Scarus ovifrons. Toxicon, v. 42, n. 1, p. 29-33, 2003.

VALENTIN, J. L. Analyse des paramètres hydrobiologiques dans la remontée de Cabo Frio (Brésil). Mar. Biol., v. 82, n. 3, p. 259-276, 1984.

VAN DEN HOEK, C.; MANN, D. G.; JAHNS, H. M. Algae an introduction to phycology. Cambridge: Cambridge University Press, 1995. $623 \mathrm{p}$.

WAKEMAN, K. C.; YAMAGUCHI, A.; ROY, M. C.; JENKE-KODAMA, H. Morphology, phylogeny and novel chemical compounds from Coolia malayensis (Dinophyceae) from Okinawa, Japan. Harmful Algae, v. 44, p. 8-19, 2015. 